precise, and intensely personal account of Wilkins's arctic experiences, and "Under the North Pole" (1931) gives his life up to the time he became involved with the "Nautilus". Mr. Thomas tells, in great and lurid detail, the story of how Wilkins first reached England, a story of which Wilkins himself makes no mention. The gypsy girl who stowed away on the "Alaskan" at Fairbanks receives no mention in Wilkins's own books; Mr. Thomas devotes nearly a page and a half to her. Some details have been changed for no apparent reason. Uncrating the planes at Fairbanks, Wilkins states that the workers complained of the cold when the thermometer read $-52^{\circ} \mathrm{F}$; Mr. Thomas gives the figure as $-20^{\circ} \mathrm{F}$.

This book gives no details of the very considerable human problems that beset the attempts to take the "Nautilus" to the North Pole, such as the differences of opinion between Wilkins and Danenhower and Lake, and the attitude of the submarine's crew. It seems obvious, from these and other discrepancies and omissions, that $\mathrm{Mr}$. Thomas did not bother to read Wilkins's books carefully before writing his biography, nor did he talk to many of the people who knew Wilkins well.

A serious error, and a detraction from Wilkins's own achievements, results from this. During the antarctic flights of 1928 , the book claims, Wilkins crossed "the Graham Land plateau . . . discovering the channels which apparently transformed the great peninsula into a chain of islands," and "discovered altogether eight new islands, three channels, and a strait, as well as an unknown land which seemed to be part of the Antarctic continent". No note or comment is added to explain that, in 1934-37, the British Graham Land Expedition showed Wilkins's channels to be glacier streams, and the strait to be non-existent, so that Graham Land is, in fact, a peninsula. Wilkins would certainly have been the first to admit this error. Without being formally trained as a scientist, he had a scientific outlook, and constantly modified his views and ideas when new evidence warranted doing so.

The book is well illustrated, but lacks an index, maps, and a bibliography.

A biography of Sir Hubert Wilkins, it is hoped, will someday get the same loving care that the Fishers devoted to the life of Shackleton. Much manuscript material on the explorer's life rests in the Stefansson Collection, and there are many people who knew Wilkins intimately, and worked with him. Until such a biography is written, $\mathrm{Mr}$. Thomas' book will serve as a satisfactory account of the life of an accomplished and important arctic explorer. JIM LоTZ

\title{
Obituary
}

\section{Ukichiro Nakaya}

Professor Ukichiro Nakaya was one of the best known and internationally prominent scientists in the field of snow and ice research. He died at Tokyo, Japan on April 11th, 1962 after a long illness. 
Dr. Nakaya was born on July 4th, 1900 at Katayamazu (now Kagashi), Ishikawa-ken, which is on the Sea of Japan. He received his Master of Science degree in 1925 from the Department of Physics of the University of Tokyo and then did additional graduate work in physics at Kings College, London, under Dr. O. W. Richardson from 1928 to 1929. He was granted a Doctor of Science degree in 1931 by Kyoto University. In 1930 he was appointed Professor of Physics at Hokkaido University at Hokkaido, Sapporo, and remained associated with that university during the rest of his life.

At the time Dr. Nakaya took over the new department of physics there was a minimum of equipment and few funds available for research. But he did have a microscope and an unlimited number of natural snow crystals during the long winters. From over 3,000 photomicrographs he established a general classification of natural snow crystals. His next step was to try to duplicate nature in the laboratory and from these studies he developed the convective snow-making apparatus and the "Nakaya diagram" of growing conditions for snow crystals. From the shape of a snow crystal, he found, one could determine the meteorological conditions in the atmosphere in which the crystal was formed. In 1940 he was awarded the Japan Academy Prize for his research on snow. His beautifully illustrated book, "Snow Crystals", was published by Harvard University in 1954 and now serves as the classic reference on snow crystal shapes and classification to both artist and scientist.

In 1941, through his efforts, the Institute of Low Temperature Science was established at Hokkaido University for studies on snow and ice. At the end of World War II he was instrumental in establishing the Institute of Agricultural Physics for the development of agriculture in cold regions. A natural teacher, he has lifted many a beginning researcher over seemingly insurmountable obstacles by his patience, understanding, and ability to make the most difficult problem appear simple.

In 1952 he was invited to conduct research at the U.S. Army Snow, Ice and Permafrost Research Establishment (since redesignated the Cold Regions Research and Engineering Laboratory). During the two-year period that followed he began his classic study of single crystals of ice, and later frequently visited the United States to continue his studies. He enjoyed field work as well as laboratory research and these studies took him to the top of Mt. Mauna Loa, Hawaii, to the Greenland Ice Cap for four seasons, and to Ice Island T-3. His pre-eminence in the field of snow and ice research was recognized by his election as a Vice-president of the Commission on Snow and Ice of the International Union of Geodesy and Geophysics.

Although he was the author or co-author of a great many scientific articles, these represent only one facet of a widely talented man who also wrote some thirty non-fiction books as well. In his earlier years he was interested in painting with oils and later became very proficient in "Sumi-e", an exacting form of traditional Japanese art using single brush strokes and black ink. He is well-known in Japan as an essayist, a critic on current topics of natural science, and as an outstanding photographer. In 1960 he received recognition of his many talents when he was selected as one of the ten most distinguished men in Japan.

He will long be remembered in the professional world through his classic research papers and through his inspiration to his students and colleagues. His many friends will remember him as a wonderful, interesting, and much beloved person who often wrote in his books and paintings, "snow crystals are the hieroglyphs sent from the sky." 